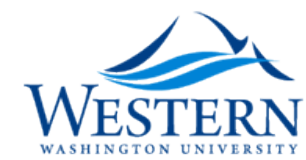

Western Washington University

Western CEDAR

Fall 1999

\title{
Excavating the New Republic: Post-Colonial Subjectivity in Achebe's Things Fall Apart
}

Christopher Wise

Western Washington University, christopher.wise@wwu.edu

Follow this and additional works at: https://cedar.wwu.edu/english_facpubs

Part of the English Language and Literature Commons

\section{Recommended Citation}

Wise, Christopher, "Excavating the New Republic: Post-Colonial Subjectivity in Achebe's Things Fall Apart" (1999). English Faculty and Staff Publications. 3.

https://cedar.wwu.edu/english_facpubs/3

This Article is brought to you for free and open access by the English at Western CEDAR. It has been accepted for inclusion in English Faculty and Staff Publications by an authorized administrator of Western CEDAR. For more information, please contact westerncedar@wwu.edu. 


\title{
EXCAVATING THE NEW REPUBLIC Post-colonial Subjectivity in Achebe's Things Fall Apart
}

\author{
by Christopher Wise
}

\begin{abstract}
"[I]t may be productive [today] to think in terms of a genuine transformation of being which takes place when the individual subject shifts from purely individual relations to that very different dynamic which is that of groups, collectives and communities ... The transformation of being ... is something that can be empirically experienced ... by participation in group praxis-an experience no longer as rare as it was before the 1960s, but still rare enough to convey a genuine ontological shock, and the momentary restructuration and placing in a whole new perspective of the kinds of private anxieties that dominate the monadized existence of the individual subject"
\end{abstract}

-Fredric Jameson “Interview” (82)

\section{Introduction}

After Frantz Fanon's and Aimé Césaire's devastating critiques of Placide Tempels' La philosophie bantoue in the mid-1950s, the hermeneutic and logocentric quest to recuperate the more overtly ontological dimensions of African culture became theoretically suspect, if not wholly untenable, following nearly three decades of speculation about Léopold Sédar Sénghor's négritude, which is now widely dismissed as an under-theorized metaphysics of blackness. ${ }^{1}$ Today, Fanon's and Césaire's analyses of Tempels' book seem more viable than ever. In a recent study by Kwame Anthony Appiah, for example, we receive due warning about the dangers of overglorifying the otherness of pre-colonial African culture, especially for the sake of commodifying its art. Furthermore, Appiah demonstrates how contemporary African writers have tended to reject the Western mandate that they recreate or reify the lost alterity of their past; or, borrowing from Sara Suleri, Appiah argues that many African artists and intellectuals do not wish to serve as "otherness machines" for late capitalist, consumer society (157). Like Fanon and Césaire then, many contemporary post-colonial critics are concerned about recent efforts to commodify African being, especially for the sake of merely enriching the West's powerful university system, or its growing complex of art and ethnological museums. 
Additionally, as Fanon has observed in Black Skin, White Masks (1982), most purely academic celebrations of African ontology, as found in the work of Tempels, Leo Frobenius, and many others, tend to disregard the more pressing social and political needs of the present. Responding to Tempels' La philosophie bantoue, Fanon warns specifically that "[i]t is not a matter of finding Being in Bantu thought, when Bantu existence subsists at the level of nonbeing, of the imponderable" (185-86). Fanon goes on to dismiss efforts like Tempels' as "rubbish" [scandale] and his rejection is no less categorical than Césaire's, who in Discourse on Colonialism (1972) demonstrates even less sympathy with Tempels' work than Fanon (34-39). Césaire, in fact, characterizes Tempels' book as "slimy and fetid" [vaseuse et méphitique] (34), ironically ridiculing Tempels' generosity and missionary zeal (38). "Since Bantu thought is ontological," Césaire quips, "the Bantu only ask for the satisfaction of an ontological nature. Decent wages! Comfortable housing! Food!" (38-39).

Given then the on-going and disproportionate distribution of the world's wealth, as well as more pedestrian problems in Africa like starvation, AIDS, and civil-war, first world scholars and teachers must never lose sight of the scandalous disjunction between their own privileged experience and the experience of oppressed Africans in places like Angola, Somalia, and the Sudan. To quote Ngugi wa Thiong'o, first world intellectuals must ceaselessly remind their constituency that the very water they drink is often "taken from the mouths of the thirsty," and the food they eat is "snatched from the mouths of the hungry" (Barrel of a Pen 74). In this sense, any purely abstract theorization of pre-colonial African being must stand condemned as worse than irrelevant: The harsh reality of contemporary existence in Africa would seem to dictate that immediate social and material demands must take precedence over speculatory efforts by scholars like Temples or Frobenius to reconstruct Africa's precolonial past. Another way of saying this might be to accept Fanon's argument that no true culture can come to life under such oppressive social conditions as currently exist, or that "[it] will be time enough to talk of the black genius when the man has regained his rightful place" (Black Skin, White Masks 187).

Nevertheless, we must also pause to consider whether or not it is possible, in the first place, to undermine the Manichean legacies of the colonizing process without first interrogating the ontological status of Africa's precolonial past, specifically by reconstructing it within a necessarily allegorical and "violent" semantic framework. ${ }^{2}$ Though such an approach obviously denies the hegemony of most contemporary antihermeneutic methodologies, particularly more vulgar post-structuralist varieties that endorse an absolute concept of difference, this study is undertaken with the conviction that Achebe's novel Things Fall Apart is worthy of close analysis not simply because it offers insight into the purely structural or syntactic dynamics of European colonialism, ${ }^{3}$ but also because of its visionary exploration of the pre-Manichean and ontological status of the pre-colonial Igbo people.

However, in the context of contemporary late capitalist society, especially in the United States and Western Europe, there would seem to be obvious difficulties in bringing the Igbo experience of being, as described by Achebe, into the interpretive horizon of a dramatically different First World orientation towards social reality. ${ }^{4}$ Still, I would insist that meaningful and benign experiences of collective being have by 
no means been wholly eradicated from contemporary existence in the West, uncanny though they may be. Here, I would cite Jameson's pertinent observation that oppositional scholars today need to reappropriate an authentically dialectical concept of ontology, or collective social being, an observation which he draws from the writings of Raymond Williams, Ernst Bloch, and Jean-Paul Sartre..$^{5}$ I would also cite Martin Heidegger's key hermeneutic concept regarding the facticity of Being, or the notion that "even if we ask, 'What is 'Being'?, we [nevertheless] keep within an understanding of the 'is,' though we are unable to fix conceptually what that 'is' signifies" (Being and Time 24-25). In "The Writer and His Community," Achebe himself has argued that while cultural differences should be respected, they should not be emphasized to the extent that one falls "into the trap of seeing the differences as absolute rather than relative" (59). ${ }^{6}$ Thus, while Achebe has consistently attacked the universalizing impulses within colonialist criticism and discourse, he nevertheless recognizes that totalizing philosophies of difference are both dogmatic and counter-productive insofar as they dismiss hermeneutic understanding altogether. In this sense, we may also reread Appiah's concern about the way in which African artists seem to be recast into the role formerly assumed by alienated modernist artists-namely, to be productive "otherness machines" for a vacuous First World marketplace-as a parallel rejection of the "post-structuralist" insistence on non-identity wherein the possibility of sameness is absolutely rejected.

Instead of focusing upon the disintegration of the basic psychic coordinates or mechanisms of Achebe's Igbo, ${ }^{7}$ in the following essay, we will focus upon the emphatically historical question of pre-European Igbo being in Things Fall Apart, especially as it pertains to the larger objectives of contemporary post-colonial theory. In this regard, I will suggest that Achebe's description of Igbo community life functions not only as a Fanonian "negation of a negation" (or counter-weight against previous literary distortions of Africa) ${ }^{8}$ but it also functions as a prophetic affirmation of post-colonial Africa's future by offering a teleological vision of a postCartesian or collective subjectivity. Achebe's depiction of the pre-European Igbo may therefore be brought into alignment with more recent efforts by post-colonial theorists like Abdul R. JanMohammad, Edward W. Said, Fredric Jameson, and many others to introduce a uniquely post-individualistic and collective subject-position, symbolically located at the "other end of historical time" (Jameson, "Imaginary and Symbolic in Lacan" 110). ${ }^{9}$

\section{Achebe and Western Philosophy}

In a lecture given at UCLA in 1984, Achebe has described René Descartes as both "the father of Western philosophy" and "the cause of a gigantic philosophical accident" ("The Writer and His Community" 50-51). Specifically, Achebe rejects the narrowness and egocentrism of Cartesian philosophy, or the cogito ergo sum of Descartes, which, he argues, functions as a defining aspect of contemporary life in the United States, for Achebe, the historical site of an enormous "ontological accident" 
(51). As a foil to Descartes, Achebe also suggests that, in the unlikely event that Socrates, Plato, or Augustine returned to the modern era, they would no doubt find African community life, like that which is described in Things Fall Apart, more appealing to them than Western individualism (50-51). To emphasize the utopian dimensions of these thinkers, Achebe remarks that

The Republic ... was after all a grand design for the ordering of men in society; and The City of God a Christian reordering of society after the destruction of the Roman Empire by pagans. In other words, philosophy for Plato and Augustine, historically equidistant from Christ, was concerned with architectural designs for a better world.

Expanding upon this thesis, Achebe particularly singles out Augustine by stating that, while recent Western literature and theory has encouraged us to think of contemporary social existence as life within a prison-house, ${ }^{10}$ he himself prefers the Catholic or Augustinian vision of social being defined as "other-centered fulfillment," or as a potentially benign "presence limiting the space in which the self can roam uninhibited" (53). ${ }^{11}$

Though unexpected, Achebe's views on Augustine tend to remind us of a fact that nearly fifteen hundred years of Christian domination in the West have tended to obscure: namely, that Augustine's City of God is primarily mystical and theurgical rather than legislative ( $\mathrm{O}^{\prime}$ Meara $\left.x x x\right)$. In this sense, Augustine does not so much offer an oppressive blueprint for Roman Catholic theocracy, as much as he offers an astonishing vision of a better world, a utopian standard by which earthly and corrupt cities may be measured and found wanting. Obviously, as a Neo-platonist philosopher, Augustine draws upon Plato's Republic in drafting his own new "republic" that is refracted through the lens of Christian doctrine and mysticism. While in Things Fall Apart Achebe does not really offer an elaborate utopian scheme like Plato in The Republic, he does create an alternative universe or reality in which community life indeed turns upon the Augustinian notion of "other-centered fulfillment" that is lauded in Achebe's speech: the notion of community life as a "presence" that deliberately and creatively restricts the freedom of individuals, but in non-oppressive ways (Achebe, "The Writer and His Community" 53).

In this sense, Achebe aims not only at rehabilitating Africa's pre-colonial past; he also wants his novel to fulfill a more primal human need by providing "an alternative handle on reality" (58). To this end, Achebe lauds Frank Kermode's definition of fictional reality as "'something we know does not exist but which helps us to make sense of, and move in, the world"' ("The Truth of Fiction" 139); and he rejects Milan Kundera's definition of the novel as " an investigation into human existence ... [that] proclaims no truth, no morality'" because it denies the novel's also important didactic and social functions ("The Writer and His Community" 55). In other words, far from evading political and social responsibility to community, Achebe asserts that the task for the novelist is rather to imaginatively bring into being a wholly "different order of reality from that which is given" ("The Truth of Fiction" 139, my emphasis). 
However, it should be clear that if Things Fall Apart offers an alternative vision of a pre-Cartesian and pre-alienated African past, it does not necessarily follow that the ontological aspects of Achebe's novel may therefore be conflated with the theological ones, which would be equivalent to suggesting that Achebe's description of the precolonial Igbo is essentially Edenic or mythical. On the contrary, Achebe describes an emphatically historical form of social existence, which nevertheless remains utopian in character. First, Achebe does not hesitate to dramatize the very real socio-historical crises and contradictions among the Igbo people, many that exist long before the arrival of the British, and that later create opportunities for the spread of Christianity. In fact, it is by now commonplace to assert that post-colonial African writers like Achebe, in recreating the pre-colonial past, wish to demonstrate that the era before the arrival of Europeans was neither idyllic nor savage, but was instead "composed of real and vulnerable people, their ancestors, not the figments of missionary and colonialist imaginations" (Lawrence 9). ${ }^{12}$

However, Achebe goes further than this by insisting that Africa's pre-colonial past was in many ways creatively superior to its historical European counterpart. ${ }^{13}$ Taking issue with reviewers of Yambo Ouologuem's Bound To Violence, for example, Achebe argues that, while pre-colonial Africans certainly had their share of faults, they nevertheless were not responsible for the basic historical fact of racism's existence, especially as a systematic doctrine or creed (79). ${ }^{14}$ Another way of saying this might be that, while Achebe's Igbo in Things Fall Apart do not inhabit an Edenic paradise, they nevertheless are not guilty of essentializing the Other on the basis of race, which is a distinctly European problem. Additionally, Achebe suggests that his Igbo do not suffer from the harmful attributes of a Cartesian and alienated world-view, or from a primal detachment from being itself. In short, if the Igbo in Achebe's novel do not live within an idyllic paradise, they do inhabit a utopian space that is free from the contradictions of both Cartesian logic and racist ideology. ${ }^{15}$

\section{Malignant Fictions: or, Achebe and Historical Situation}

Before delineating the more formal features of this non-Cartesian utopian space, it is important to acknowledge, at least in passing, the documented failures or obvious social contradictions of the pre-colonial Igbo in Things Fall Apart, especially their "caste" system, their practice of ritual murder (whether due to oracular promptings, or due to their fear of biological twins), and their oppressive patriarchy, particularly evident in the case of Okonkwo. In his essay "The Truth of Fiction," Achebe himself offers one helpful way of approaching these problems when he praises a scientific study of infant mortality in modern-day Nigeria, which he describes as both "poignant" and "perspicacious" (142), and when he criticizes the practices of a contemporary Nigerian witch-doctor, which he describes as both "maniacal" and "pitiful." However, for Achebe, Dr. Sanya Onabamiro's Why Our Children Die does not necessarily offer a better solution to the problem of infant mortality in Nigeria merely because he offers a scientific one; rather his ideas are preferable because they are both 
imaginatively and creatively superior to those of his superstitious counterpart. Hence, Achebe argues that

\begin{abstract}
the insights given by Dr. Onabamiro into the problem of high infant mortality, however incomplete future generations may find them, are infinitely more helpful to us than the diagnosis of a half-mad religious fanatic. In conclusion, there are fictions that help and fictions that hinder. For simplicity, let us call them beneficent and malignant fictions. (143)
\end{abstract}

Achebe's approach to this question may have been informed by the work of Claude Lévi-Strauss, whom Achebe draws from in establishing his own informal theories of myth and language ("Language and the Destiny of Man" 136-37). ${ }^{16}$ In this regard, Achebe implies that, regardless of the particular aesthetic, religious, or cultural form, all symbolic expressions of human culture function in the first instance as creative responses to their various social situations, or they function as dynamic attempts to resolve the various crises of material necessity in the on-going historical struggle to "wrestle a realm of freedom from the realm of necessity" (Marx, Capital III 820). When Nwoye abandons Okonkwo's obi for the Christian mission, for example, Achebe tells us that "[i]t was not the mad logic of the Trinity that captivated him . . . It was the poetry of the new religion, something felt in the marrow" (Things Fall Apart 104). More specifically, Nwoye finds in the new religion a more satisfying "answer [to the] persistent question that haunted his young soul-the question of the twins crying in the bush and the question of Ikemefuna who was killed" (my emphasis).

Thus, while Nwoye may be overwhelmed by the poetry of the new religion, he is actually indifferent to its objective content, which he does not understand. ${ }^{17}$ For similar reasons, the stigmatization of specific tribal members as osu, or taboo outcasts, also tends to facilitate the success of the Christian missionaries (111), though Achebe seems to imply that the problem of patriarchy among the Igbo is more specific to Okonkwo rather than the tribe as a whole. In other words, Okonkwo's misogyny is largely a personal failing, resulting from the exaggerated shame and aversion he feels for his father (9-10). Still, throughout the novel, the attitudes of Igbo men towards women are often depicted by Achebe as both harmful and repressive at best. ${ }^{18}$

We may conclude then that if Achebe believes the pre-colonial Igbo enjoyed a less alienated form of social existence before the arrival of the British, he also implies that it was, in many instances, a less humane one. Even Okonkwo, for example, is sickened by the death of Ikemufuna, though he himself plays the largest role in it (44). Later, Achebe describes Obierika, a tribal elder, as being disenchanted with oppressive Igbo traditions such as the "throwing away" of twins and other seemingly arbitrary social customs (87), the former affecting him personally. Towards the novel's conclusion, Achebe also states that "there was a growing feeling [among the Igbo] that there might be something in [the new religion] after all, something vaguely akin to method in the overwhelming madness" (126). Besides the question of the twins, the $o s u$, and other unsatisfactory tribal customs, this growing feeling about the new "lunatic religion" is also strengthened by the fact that the British had significantly improved the local 
economy, so that now "much money flowed into Umuofia." Additionally, to the increasing dismay of Okonkwo, the Igbo become appreciative of the white man's medicine as well as his government and his schools (128-29).

Nevertheless, Achebe's even-handedness in depicting the positive imports of British culture should not blind us to the novel's more fundamental aim: that is, as we have already seen, to create a wholly alternative fictional reality as a means of engaging and modifying existing colonial and post-colonial societies (Achebe "The Truth of Fiction"139). In this regard, what may be most remarkable about Things Fall Apart is its ability to both deploy and subvert the traditional European novel form itself in the service of purposes distinct from those which have historically defined it. Specifically, Achebe transforms the "bourgeois epic" of homelessness and alienation into a recuperative celebration of collective social existence.

\section{Pre-Colonial Igbo Ontology in Things Fall Apart}

Though the theoretical writings of Frantz Fanon may be classified as a radical variety of phenomenological existentialism, especially insofar as they are grounded in the Marxian philosophy of Jean-Paul Sartre, many contemporary post-colonial theorists prefer to emphasize the more tenuous connections between Fanon and more popular theorists like Jacques Lacan. ${ }^{19}$ It is at least ironic, however, that the critic who is chiefly responsible for alerting us to the dangers of celebrating African ontology was himself an old-fashioned hermeneutic or even logocentric thinker. In other words, despite the efforts of Homi K. Bhabha, and many other contemporary critics, Fanon was by no means a post-structuralist or Derridean thinker, largely because he, like Sartre before him, posits a pre-linguistic (or pre-symbolic) form of human consciousness. ${ }^{20}$ However, not only Fanon but Achebe as well respects the now "anachronistic" hermeneutic distinction between text and being, or the currently unpopular bifurcation between what Wilhelm von Humboldt once termed Sprache [articulated language] and Rede [ontological speech]. ${ }^{21}$

In his essay "Language and The Destiny of Man," for example, Achebe, states specifically his view that "language is not inherent in man-the capacity for language, yes; but not language. Therefore there must have been a time in the very distant past when our ancestors did not have it" (88, my emphasis). The implications of the theoretical distinction made by Achebe have been developed most fully in Heidegger's Being and Time (1926), where Sprache, or the ordinary language of daily life, is separated from Rede, which is defined as the ontologically prior human faculty for ordinary discourse (203-4). In this sense, Achebe's belief about the dual nature of language may not be incidental to his descriptions of the pre-colonial Igbo in Things Fall Apart but may instead be that which enables him to explore the dramatic possibilities of an alternative form of subjectivity, which is fundamentally nonalienated, pre-Cartesian, and collective in orientation.

In other words, while Heidegger advocated that we develop a new relationship to language, rejecting our present-day relationship with language as a barrier that prevents us from an experience of ontological plenitude, Achebe creates an alterna- 
tive utopian reality in Things Fall Apart wherein its inhabitants enjoy the kind of relationship with their language that Heidegger advocated. However, I am not suggesting that the actual Igbo people themselves enjoyed such a non-alienated relationship with their language, which is of course both immaterial to my thesis and indeterminate. In fact, Achebe himself asserts that his descriptions of the Igbo people are "merely localized impressionistic illustrations taken from [his] own experience of growing up in Ogidi in the 1930s and 1940s" ("The Igbo World and Its Art" 66), and he also suggests that the world of his childhood probably exists at present only in his dreams (67). Hence, whatever the Igbo people actually are or were, the fact remains that the text of Achebe's Things Fall Apart, like that of Heidegger's Being and Time, functions in the first instance as a socially symbolic attempt to imagine a radically alternative form of community existence in which human experience is not based upon a Cartesian subject-object duality, and in which human beings enjoy a more dynamic, non-alienated relationship to their language.

Heidegger's notion of Dasein [Being-there] suggests that, before the "nightmare" of post-Socratic history, human beings first existed in a world in which the human mind was not fundamentally distinct from matter. However, it is crucial to Heideggerian thought that there also must have existed a semantic dimension to the world of Dasein [or, the nonsubjective individual] before that world could be expressed linguistically. Heidegger's Rede [Speech], like Achebe's notion of an innate human "capacity" for language, is therefore the ontologically prior "openness" without which it would be impossible for Sprach [articulated language] to come into being. Like Schleiermacher and Humboldt, Heidegger then establishes two distinct spheres of language, a higher realm in which authentic meaning may occur and a lower realm of common, ordinary or "fallen" language. ${ }^{22}$ However, while in the early Heidegger, Dasein [or "man"] serves as Being's privileged space of disclosure, the later Heidegger moves towards a more radical anti-humanism in which Dasein is no longer the ultimate locus of truth and meaning. In other words, the later Heidegger, not unlike the later Saussure, makes the emphatically anti-Cartesian assertion that it is language and not the subject that speaks (Unterwegs zur Sprache 12). Furthermore, the later Heidegger also suggests that it is in poetic language itself, or poetic language as Logos, that the ultimate "unconcealment" [alethia] of both truth and being occurs. But he also insists that Rede, defined throughout his writings in terms of ontological silence, must remain the necessary precondition for the "unconcealment" of Being (Erläuterungen zu Hölderlins Dichtung 69).

In contemporary Western society, which Achebe has characterized as an ontological "mistake," it is commonly assumed that language originates from the speaking subject, a notion that Achebe dramatically rejects in his depiction of the pre-colonial Igbo. In other words, if Heidegger depicts the individual being [or Dasein] as the object (rather than the subject) of metaphysical thought, Achebe depicts the precolonial Igbo in Things Fall Apart as similarly inhabiting a world in which there seem to be no speaking subjects in any strictly Cartesian sense. For example, when the Umofia Igbo are called by name from outside their huts, they exhibit a marked suspicion of their language, which they seem to view as an autonomous, powerful, and reifying force: 
'Ekwefi!' a voice called from one of the other huts. It was Nwoye's mother, Okonkwo's first wife.

'Is that me?' Ekwefi called back. That was the way people answered calls from outside. They never answered yes for fear it might be an evil spirit calling. (29)

This brief illustration suggests that the basic epistemological orientation of Achebe's Igbo is radically different from that of what Achebe calls, "the true modern, Western man [who has] made the foundation of his philosophical edifice, including the existence of God, contingent on his own first person singular" ("The Writer and His Community" 51). Ekwefi's refusal to automatically validate the interpolation of her name into any form of disembodied language also suggests the pre-colonial Igbo's awareness of language's more violent and oppressive features, an epistemological sophistication notably absent in the order of things of the Cartesian West.

Achebe makes clear throughout Things Fall Apart, as well as throughout his nonfictional essays, that he believes the Igbo have experienced a fundamentally different, if not superior, relationship between their lived bodies and their discursive language than any presently known in the modern world. Hence, when the egwugwu, or the judicial branch of Igbo society, address individual members of the local community, they always refer to each individual as a "body" rather than a name (64). Similarly, Achebe informs us that during festivals, ritual occasions, or periodic social crises, the masked forms or figures of long-dead ancestors will often return to the community, now "speaking an esoteric dialect in which people are referred to as bodies: 'The body of so-and-so, I salute you!"' ("The Igbo World and Its Art" 66). As in the case of Ekwefi's refusal to directly engage any disembodied or unseen voice, in all of these instances Achebe's Igbo seem to exist more as objective products of metaphysical thought rather than the masterful, subjective agents that populate the Cartesian West. Furthermore, Achebe describes the defining or interpolating discourse of the precolonial Igbo as an "esoteric" dialect or language that is largely inaccessible to the "living" person (Things Fall Apart 63), a seemingly anachronistic awareness that the totality of language is never entirely available to the individual subject or Dasein. ${ }^{23}$

In both the text of Things Fall Apart and in his published essays, Achebe has consistently affirmed the importance of traditional folk "literature" itself, especially as a discursive network of proverbs, aphorisms, and metaphors that adds coherence and unity to the lives of individuals within the community. In Things Fall Apart, Achebe demonstrates the importance of folk wisdom and "literature" with repeated reference to Igbo proverbs and folk-tales, a narrative strategy which, in fact, stabilizes and undergirds the novel's most basic structure. ${ }^{24}$ Similarly, Achebe demonstrates how the folk wisdom of the pre-colonial Igbo enables the historicity of the past to serve a meaningful purpose within the time of the present, facilitating "comings and goings" between "the land of the living" and the "domain of the ancestors" (85). Not surprisingly, Achebe has reaffirmed in a recent interview his largely conservative view that people who don't have any sense of their own history must be condemned to "starting again every day," or to beginning again as "new men in the world every 
day and this is terrible [my emphasis]" (Talking With African Writers 54). In regards to recently evolving concepts of a collective subject position, it may therefore be worth considering Achebe's view that there is no better preparation for survival within the disorienting world of modernization than the study and preservation of the traditional cultures of the past ("What Has Literature Got to Do with It" 170).

Additionally, Achebe's description of the Oracle of the Hills and Caves in Things Fall Apart implies that the pre-colonial Igbo may live at a time when the necessary ontological conditions are present for what Heidegger called the "unconcealment" [alethia] of truth and beings. First, Heidegger's celebration of ontological silence, a necessary precondition so that authentic Language [or Logos] might speak, is dramatically echoed by Achebe in his characterization of pre-colonial Igbo community life in terms of its "vibrant" (7), "complete" (39), and even "perfect" silence (8). As Walter J. Ong might put it, Achebe's Igbo seem to be "rooted in a 'speaking silence'" (Interfaces of the Word 23). Additionally, Achebe shows us that the Oracle of the Hills and Caves is not simply a terrifying supernatural voice but also a pragmatic mediator within the community, giving personal advice, resolving disputes (12), and advising about warfare (9). On occasion, the Oracle can even be teased if its demands seem either unreasonable or dubious (15), not unlike Heideggerian notions of the Logos as playful or ludic. ${ }^{25}$

While homologous in some ways with much recent post-structuralist theory, Achebe's views on language's autonomy in pre-colonial Igboland should nevertheless not be confused with either Roland Barthes's fetishizing of the text, or the Derridean notion that "there is nothing outside of the text" (Of Grammatology 158). In fact, Achebe's depiction of language's unique role in human affairs more closely parallels the post-Kantian and anthropological linguistics of Wilhelm von Humboldt, the intellectual precursor of Heidegger. ${ }^{26}$ Like the Igbo in Things Fall Apart, speakers in Humboldt's linguistic system are both shaped or molded by language, which is described by Humboldt as a creative and autonomous force [ergon], but they also possess an inward or "in-dwelling" sense of language's "prelinguistic" or semantic dimensions [energeia]. The word is therefore not only outside the monadic subject; it is also "a living potential in the human interior" (Ong The Presence of the Word 232). As George Steiner puts it, "language is a 'third universe' midway between the phenomenal reality of the 'empirical world' and the internalized structures of consciousness" (81, my emphasis). ${ }^{27}$ Humboldt himself writes, "Even though language is wholly inward, it nevertheless possesses at the same time an autonomous, external identity and being which does violence to man himself" (82).

In Things Fall Apart, as we have seen, Achebe shows us how the Igbo possess an uncanny awareness of language's often harmful and alienating nature, the powerful being of language that evokes in its subjects of Igboland the greatest caution and dread. This is most evident, for example, in the case of Ikemufuna of whom the Oracle demands a ritual sacrifice. However, we are also shown how the Igbo are not (as in Barthes, Derrida, and other poststructuralists) the "pure" products or "constructs" of their language (that is to say, the purely powerless products of human language), but they are instead endowed with a strikingly logocentric and powerful individualism, an in-dwelling ability to determine their own fate, status, and well-being within the 
real or historical world. ${ }^{28}$ This is especially evident in the case of Okonkwo whom, Achebe informs us, is "one of the greatest men of his time" (6).

In the opening lines of the novel, Achebe states plainly that Okonkwo's considerable fame throughout the land is the result of his "solid personal achievements" (3), and that Okonkwo is a man "clearly cut out for great things" (6). Achebe also emphasizes that Okonkwo's flaws, as well as his strengths, are uniquely his own, rather than the result of any specific social or historical contradictions among the Igbo people. Okonkwo's fear of failure, for example, is described by Achebe as "deeper and more intimate than the fear of evil and capricious gods and of magic" (9). From the beginning of the novel, we are told, Okonkwo's fear is "not external but [lies] deep within himself [my emphasis]." In his essay, "The Writer and His Community," Achebe makes this point even more plainly by asserting that "[t]he Igbo are second to none in their respect of the individual personality" (57). Achebe adds that "the Igbo posit an unprecedented uniqueness for the individual by making him or her the sole creation and purpose of a unique god-agent" (57-58). The Igbo belief that individuals within the community possess a personal god or chi reaffirms Achebe's suggestion that human subjects are not only constituted by either language in its outward and more "violent" dimensions, but they are also endowed with a prelinguistic and deeply inward capacity to understand their world. Achebe tells us, for example, that Okonkwo's personal success was not regarded by the Igbo as the result of his own luck or good fortune (19); rather the Igbo believe that Okonkwo achieves success chiefly through his own initiative, illustrated by Achebe with the Igbo proverb that " $[\mathrm{w}] \mathrm{hen}$ a man says yes, his chi says yes also." This is not to say, however, that one's "chi" is strictly self-interested. For example, when the character Chielo assumes the role of priestess of Agbala, Achebe describes her as someone who is literally "possessed by the spirit of her god" (70), her very body at times transformed in "fantastic" and "miraculous" ways (75). Early in the novel, Achebe states that "[a]nyone seeing Chielo in ordinary life would hardly believe she was the same person who prophesied when the spirit of Agbala was upon her" (35). Later, when Ekwefi, the first wife of Okonkwo, follows Chielo and her daughter to the Oracle of the Hills and Caves, Chielo is portrayed by Achebe as "inhuman" if not monstrous (75).

Finally, the fictional representation of a collective form of subjectivity in Things Fall Apart dramatically affirms Achebe's vision of community life that offers a sense of "other-centered fulfillment" to its inhabitants ("The Writer and His Community" 53). This principle is demonstrated throughout Things Fall Apart by way of the ceremony of the kola nut, a sacramental ritual that binds the Igbo community together and provides a context within which meaningful human exchange may occur. "To bring the kola," we are told, "is to bring life" (5). Extending authentic courtesy to one's guests, or extending welcome to the Other, for Achebe's Igbo, serves as the necessary foundation of civil society. Hence, during the New Yam Festival, Achebe tells us that "every man whose arm was strong ... was expected to invite large numbers of guests from far and wide" (26). In fact, an individual's most basic humanity for the precolonial Igbo seems directly related to his or her willingness to serve as a generous host to others within the community (81). Achebe seems to imply then that the social and ethical obligation of welcoming the Other must be fundamental to any coherent 
concept of subjectivity within human society. Any notion of being in Things Fall Apart must therefore be defined in terms of the subject's most basic ethical obligation to the Other, as an Emmanuel Levinas, for example, might advocate, rather than in any anarchistic or postmodernist sense of being as a kind of non-dialectical or highly aestheticized subjectivity (if it can still be called that). ${ }^{29}$

\section{Conclusion}

Though Achebe rejects the stereotypical characterization of Africa as a place where "there are no real people ... only forces operating [Achebe's emphasis]" (Talking With African Writers 56), he has also described the Igbo World as "an arena for the interplay of forces ... a dynamic world of movement and of flux [and] restless dynamism" ("The Igbo World and Its Art" 62). However, for Achebe, the pre-colonial Igbo world is finally a lost world, or a world that remains significant only within the immediate context of present day political struggle within Africa (Talking With African Writers 50). Hence, we must not forget that, in the second half of Achebe's novel, Okonkwo becomes a quixotic figure of sorts, his suicide at the conclusion serving as a symbolic marker by which we can measure the extent of the Igbo community's deterioration or secularization. ${ }^{30}$ In other words, in the second half of the novel, Achebe focuses upon the dissolution of Igbo ontology, or upon the disintegration of the most basic social and psychological structures of the pre-colonial Igbo, as well as the imposition of a whole new set of organizing structures: most obviously, a Cartesian rather than an ontological and collective subjectivity.

In Black Skin, White Masks, Fanon has observed that "every ontology is made unattainable in a colonized and civilized society" (109). Like Fanon, Achebe suggests that for the pre-colonial Igbo to be inducted into colonial society, the abandonment of a previously more collective social form of existence is henceforth mandated, so that the physically painful construction of a colonized subjectivity may be violently imposed upon the native: namely, a Manichean subjectivity. It is in this sense that the second half of Achebe's Things Fall Apart dramatically depicts the peripeties of the Manichean drama, or it depicts the "slow composition of [the] self as a body in the middle of a spatial and temporal world" (Fanon, Black Skin, White Masks 111). The concluding tragedy of Okonkwo is therefore the tragedy of a novel-hero for whom it is utterly impossible to undergo Fanon's Manichean restructuration of self and world.

Nevertheless, a strictly Fanonian approach to Things Fall Apart, as we have seen, cannot finally do justice to the complexity of Achebe's novel, nor to the historical situation to which encomiastic novels like Things Fall Apart respond. This is, in part, because Fanon (like most theorists of his generation) fails to take into account the unavoidably logocentric basis of his own philosophical position, most evident in his precipitous dismissal of Tempels' La philosophie bantoue. If Fanon, Césaire, and others once had good reason for marginalizing the largely well-intended (if untimely) efforts of Tempels', there may now be good reason for us to reevaluate this road not taken. 
In other words, while the ultimate priority of Africa's basic material needs must be continually reasserted within the first world context, as Ngugi rightly reminds us, the West's present course of steadfast and deliberate deafness to these needs makes such condemnations seem unhelpful luxuries, the privileged rancor of a comprador intelligentsia. In the American academy, for example, where the "pragmatic" and neoLiberal separation of the spheres of the personal from the political routinely prohibits "deontological" moral praxis, ${ }^{31}$ it seems unlikely that any significant changes in present attitudes towards relations of uneven distribution of the world's economic resources will be forthcoming. In such a context, it may well be asked how such reform can take place until the dramatic lifeworlds of Africans like Achebe can be effectively transported into the interpretive horizons (or "lifeworlds") of those who inhabit the more privileged West. Whatever the historical significance of Things Fall Apart for modern Nigerians and other postcolonial Africans, what may therefore be most crucial about Achebe's novel for us today is the hermeneutic understanding that it engenders, its effective clearing of our own false prejudices so that our most basic humanity may be awakened.

However, if Achebe's novel is successful in this regard, its success stems from the fact that it addresses a truly transcultural, even universal, dilemma of post-oral humanity, which is not strictly an economic question: that is to say, the demise of what Ong calls "oral-aural" cultures wherein the Eventness of the Spoken Word is increasingly forgotten (The Presence of the Word 17). It is therefore entirely fitting that Okonkwo's tale concludes with his cryptic marginalization as a brief footnote within the history text of a British colonizer. While Okonkwo's tragedy is specific to colonial Igboland, and to the colonial encounter throughout the African continent, it also speaks to many far-reaching aspects of humanity's changing relationship to language during the last six hundred years ${ }^{32}$ In this sense, the story of Okonkwo does not really belong to Africa alone but to the entire human race.

\section{NOTES}

1. See René Ménil's Tracées: Identité, négritude, esthétique aux Antilles, René Depestre's Bonjour et adieu à la négritude, James Clifford's "A Politics of Neologism: Aimé Césaire" in The Predicament of Culture, Amiri Baraka's chapter "Aimé Césaire" in The Leroi Jones/Amiri Baraka Reader, and Onwuchekwa Jemie Chineweizu and Ihechukwu Madubuike's "The Leeds-Ibadan Connection: The Scandal of Modern African Literature."

2. See Theodor W. Adorno's Aesthetic Theory (321). Also see Jameson's Late Marxism, where we find the comments that in his Aesthetic Theory, Adorno demonstrates how "the reifying impulse in modern art [and its criticism] is affirmed as a necessity and evaluated positively" (21). One may also refer to the Benjaminian notion of allegory in this context, which is defined here in terms of an emphatically self-negating constellation or Darstellung [representation] (50).

3. In an interview entitled "The Post-modern Condition: The End of Politics?," Gayatri Spivak states her agreement with Pierre Macherey that the main task for us today "is not to recover a lost consciousness, but to see ... the itinerary of the silencing [my emphasis]" (31).

4. The concept of "horizon" employed in this essay may be found in Martin Heidegger's Being and Time. Translators John Macquarrie \& Edward Robinson's comment that while "[w]e tend to think of a horizon as something which we may widen or extend or go beyond, Heidegger seems to think of it as something which we can neither widen nor go beyond, but which provides the limits for certain intellectual activities performed 'within it' [my emphasis]" (1ff). Also see Hans-Georg Gadamer's Truth and Method (302-7).

5. See Jameson "Interview" (82). 
6. In discussing his experiences teaching African literature in the United States, Achebe also relays the following anecdote: "I remember a white American boy who came to me very tense, after reading Things Fall Apart, and saying 'This Okonkwo is my father!' Now I'd never in my wildest dreams thought of Okonkwo as a White Anglo-Saxon Protestant! But this is what literature is about and why it's worth doing. Otherwise why go to America to teach African literature?" (Talking With African Writers 56).

7. See Fanon's discussion of Mannoni's Prospero and Caliban: The Psychology of Colonization in Black Skin, White Masks (96-97).

8. For example, Abdul JanMohammad's chapter "Chinua Achebe: The Generation of Realism," in Manichean Aesthetics, specifically employs a Fanonian interpretive model, encapsulated by Fanon's well-known three "stages" of the colonized writer's intellectual development, which are enumerated in The Wretched of The Earth (222-23).

9. See JanMohammad and David Lloyd's "Introduction: Toward a Theory of Minority Discourse: What Is To Be Done?," where they state that "[t]he project of systematically articulating the implications of [a collective] subject-position ... must be defined as the central task of the theory of minority discourse" (9). Also, see Anders Stephanson's "Regarding Postmodernism: A Conversation with Fredric Jameson"; Edward Said's "Orientalism Reconsidered"; David F Ruccio's "Failure of Socialism, Future of Socialists?"; and Jean-Luc Nancy's The Inoperative Community.

10. For example, see Foucault's discussion of Jeremy Bentham's panopticon in Discipline and Punish: The Birth of The Prison, or Max Weber's rather monolithic description of contemporary society as an "iron-cage" in The Protestant Ethic and the Spirit of Capitalism (181).

11. As the son of Anglican Christians, Achebe has written that Augustine's very name and ecclesiastical title, which he saw as a boy inscribed in his father's copy of The West African Churchman's Pamphlet, seemed for him to possess an "elusive and eternal quality, a tantalizing unfamiliarity which [he] always found moving" ("Named for Victoria, Queen of England" 37). Like Malcolm X, who described Augustine as a great black African saint (The Autobiography of Malcolm X368), Achebe seems to find in Augustine a philosophical ally who shares many of his deepest concerns and convictions.

12. Lawrence is quoted appreciatively in Achebe's essay "Colonialist Criticism" (Hopes and Impediments 81).

13. For example, Achebe argues that the art of Africa mostly revitalized an exhausted European art, following the various discoveries of Picasso and others of masks and sculpture from Africa. See Achebe's "An Image of Africa: Racism in Conrad's Heart of Darkness" (16-17) and "Colonialist Criticism" (88-89).

14. For a helpful though brief introduction to the historical development of systematic theories of race in Europe, see Paul Bohannan and Philip Curtin's Africa and Africans (50-61).

15. In fact, the former may very well establish the basic epistemological conditions which tended to facilitate the validation of the later.

16. For example, see Lévi-Strauss's discussion of body painting practices among the Caduveo Indians in Brazil (Tristes Tropiques 196-97), which Jameson builds upon in The Political Unconscious (77-80), and Lévi-Strauss's similar observation in The Savage Mind [La pensée sauvage] that "the savage mind totalizes" (245).

17. For Nwoye, Achebe tells us, the very words of the new Christian hymns were "like the drops of frozen rain melting on the dry plate of the panting earth" (Things Fall Apart 104).

18. For example, Okonkwo and a friend are shocked at the thought that there might exist some tribes where the children belong to the wife rather than the husband, and at the suggestion that a woman might lie on top of a man during sexual intercourse (Things Fall Apart 51). However, Achebe does emphasize that the Igbo word for medicine [agadi-nwayi] means "old woman" (89), implying that the tribe's power comes from the feminine, and that, despite Okonkwo's persistent hatred for women, for the Igbo people in general, the motto "Mother is Supreme" seems to be a more characteristic attitude towards the feminine (94). Furthermore, while neighboring tribes may "haggle and bargain [for a bride] as if they were buying a goat," Achebe suggests that the Umuofia-Igbo are generally less misogynistic in their own practices (51). Achebe himself comments as follows: "There is an ambivalence to women in traditional [Igbo] society ... [T]here are these attitudes that suggest that there are two streams in the minds of our people: one in which women are really oppressed and given very low status and one in which they are given very high honor, sometimes even greater honor than men, at least if not in fact, in language and metaphor. I think this suggests that in this situation the role of the woman has not yet been fully worked out, that we are still ambivalent about it" (Talking With African Writers 53). 
19. For example, see Homi K. Bhabha's "Remembering Fanon: Self, Psyche, and the Discourse of Colonialism" (xix-xx).

20. For example, Fanon often suggests that subjective desire is in fact prior to one's interpellation into language, as when he asserts the following: "I came into the world imbued with the will to find a meaning in things, my spirit filled with the desire to attain to the source of the world, and then I found that I was an object in the midst of other objects" (Black Skin, White Masks 109). While it is commonplace to suggest that existentialism served in history as both the ethical and political branch of phenomenology, many contemporary post-colonial critics have been reluctant to fully articulate the theoretical implications of Fanon's indebtedness to phenomenological and hermeneutic philosophy. One notable exception is Henry Louis Gates, Jr., who has recently argued that we must "rehistoricize" Fanon, rather than transform him into "a kind of icon or 'screen memory'" (470).

21. See Kurt Mueller-Vollmer's "Introduction" (12-17).

22. In opposition to the hegemony of Derridean theory, this distinction is also preserved by Marxist theorists like Walter Benjamin, Theodor Adorno, Fredric Jameson, and numerous others.

23. Note Heidegger's pertinent comment that "the perceiving of what is known is not a process of returning with one's booty to the 'cabinet' of consciousness after one has gone out and grasped it; even in perceiving, retaining, and preserving, the Dasein which knows remains outside, and it does so as Dasein [Heidegger's emphasis]" (Being and Time 89).

24. In the text of Things Fall Apart, Igbo proverbs are cited on sixteen separate occasions, and folktales are retold on eight occasions.

25. For example, note the following brief anecdote: "When [Obiako's] father had not been dead very long, he had gone to consult the Oracle. The Oracle said to him, 'Your dead father wants you to sacrifice a goat to him.' Do you know what he told the Oracle? He said, 'Ask my dead father if he ever had a fowl when he was alive.' Everyone laughed heartily except Okonkwo, who laughed uneasily because, as the saying goes, an old woman is always uneasy when dry bones are mentioned in a proverb. Okonkwo remembered his own father" (Achebe, Things Fall Apart 15).

26. If Heidegger's proclivity for fascist politics renders him suspect today, it is well to remember that politically cogent theorists like Walter Benjamin, Theodor Adorno, Fredric Jameson, and many others are also heirs to Humboldt's linguistic legacies. To align Achebe with Heidegger does not then necessarily imply that one "depoliticizes" him (although this is clearly a danger).

27. Anticipating Jameson's more politicized account in The Political Unconscious (108-9) and Late Marxism (67), George Steiner in After Babel shows us how the implications of Humboldt's linguistic theories have scarcely been realized or appreciated at present, especially Humboldt's insights into those potentially harmful attributes of language that are largely outside human control (82).Steiner states at greater length, "More than a century before the modern structuralists, Humboldt notes the distinctive binary character of the linguistic process: it shares, it mediates between, the crucial antinomies of inner and outer, subjective and objective, past and future, private and public. Language is far more than communication between speakers. It is dynamic mediation between those poles of cognition which give human experience its underlying dual and dialectical form" (83).

28. Achebe's development of a "collective" or postcolonial subject position therefore radically departs from recent developments in Western postmodernist theory suggesting the possibility of a "schizoid" or "fragmented" subjectivity, as found, for example, in the writings of Deleuze and Guattari, as well as Jean Baudrillard, and others. Also, see JanMohammad and Lloyd's "Introduction: Towards a Theory of Minority Discourse" (15-16).

29. See, for example, Michel Foucault's often-cited "break" with the dialectic and the advent of the "mad philosopher," i.e., the retreat into the psychological monad (Language, Counter-Memory, Practice 41). For a more recent and technologically-oriented account of the "postmodern subject," also see Mark Poster's "A Second Media Age?" (80-84).

30. Any investigation of Okonkwo as quixotic hero would also need to be recast in terms of competing Marxian meta-narratives, pitting the tribal versus the imperial and/or capitalist modes of production proper, rather than, say, old-fashioned feudal and mercantile (or early) capitalist modes of production in 16th-century European society (Jameson, The Political Unconscious 95). For example, before the arrival of the British missionaries in Eastern Nigeria, the Igbo community in Things Fall Apart already trades in maize (24) and tobacco (27), both fruits of the Colombian exchange. Additionally, many Igbo, like Okonkwo, possess firearms and are cognizant of the existence of both white men and slavery (99), despite the relative 
isolation from non-Igbo cultural currents.

31. Besides the often-cited writings of Richard Rorty, Edith Wyschogrod articulates this position in her "deontological" study of contemporary moral theory, Saints and Postmodernism.

32. See Ong's Interfaces of the Word (17-22).

\section{WORKS CITED}

Achebe, Chinua. "The Igbo World and Its Art." Hopes and Impediments: Selected Essays. New York: Anchor Books, 1990.

. "Language and the Destiny of Man." Hopes and Impediments: Selected Essays.

Things Fall Apart. London: Heinemann, 1989.

"The Truth of Fiction." Hopes and Impediments: Selected Essays.

"What Has Literature Got to Do with It?" Hopes and Impediments: Selected Essays.

. "The Writer and His Community." Hopes and Impediments: Selected Essays.

Adorno, Theodor W. Aesthetic Theory. London: Routledge \& Kegan Paul, 1984.

Appiah, Kwame Anthony. In My Father's House: Africa In The Philosophy of Culture. New York: Oxford University Press, 1992.

Augustine. City of God. New York: Penguin Books, 1984.

Baraka, Amiri. The Leroi Jones/Amiri Baraka Reader. New York: Thunder's Mouth Press, 1991.

Bhabha, Homi K. "Remembering Fanon: Self, Psyche, and the Discourse of Colonialism." Foreword. Black Skin, White Masks. By Frantz Fanon. London: Grove Press, 1986.

Bohannan, Paul, and Philip Curtin. Africa and Africans. 3rd Edition. Prospect Heights, IL: Waveland Press, 1988.

Césaire, Aimé. Discourse on Colonialism. New York: MR Press, 1972.

—. Discours sur le colonialisme. Paris: Présence Africaine, 1955.

Chineweizu, Onwuchekwa Jemie, and Ihechukwu Madubuike. “The Leeds-Ibadan Connection: The Scandal of Modern African Literature." Okike 13 (January 1979): 37-46.

Clifford, James. The Predicament of Culture. Cambridge, MA: Harvard University Press, 1988.

Depestre, René. Bonjour et adieu à la négritude. Paris: Robert Lafont, 1980.

Derrida, Jacques. Of Grammatology. Trans. Gayatri Chakravorty Spivak. Baltimore: Johns Hopkins University Press, 1974.

Fanon, Frantz. Black Skin, White Masks. New York: Grove Press, 1982.

-. Peau noire, masques blancs. Paris: Éditions du Seuil, 1965. The Wretched of The Earth. New York: Grove Weidenfeld, 1991.

Foucault, Michel. Discipline and Punish: The Birth of The Prison. New York: Vintage, 1979. . Language, Counter-Memory, Practice. Ithaca, NY: Cornell University Press, 1977.

Gadamer, Hans-Georg. Truth and Method. 2nd Revised Edition. New York: Crossroad, 1991.

$\rightarrow$ Gates, Henry Louis, Jr. "Critical Fanonism." Critical Inquiry 17 (Spring 1991): 457-70.

Heidegger, Martin. Being and Time. San Francisco: Harper \& Row, Publishers, 1962.

__. Erläuterungen zu Hölderlins Dichtung. Frankfurt: Vittorio Klostermann, 1971.

__. Unterwegs zur Sprache. Pfullingen: Verlag Günter Neske, 1975.

Jameson, Fredric. Late Marxism: Adorno, or The Persistence of The Dialectic. London: Verso Press, 1990.

- "Imaginary and Symbolic in Lacan." The Ideologies of Theory: Volume 1. Minneapolis: University of Minnesota Press, 1988.

_. "Interview (with Leonard Green, Jonathan Culler, and Richard Klein)." Diacritics 12 (Fall 1982): 3 .

- The Political Unconscious: Narrative as a Socially Symbolic Act. Ithaca, NY: Cornell University Press, 1981.

JanMohammad, Abdul R. Manichean Aesthetics: The Politics of Literature in Colonial Africa. Amherst: The University of Massachusetts Press, 1983.

JanMohammad, Abdul R., and David Lloyd. “Introduction: Toward a Theory of Minority Discourse: What Is To Be Done?" The Nature and Context of Minority Discourse. Oxford: Oxford University Press, 1990.

Lawrence, Margaret. Long Drums and Cannons. London: Macmillan, 1968.

Lévi-Strauss, Claude. The Savage Mind. Chicago: University of Chicago Press, 1966. . Tristes Tropiques. New York: Penguin Books, 1992.

Malcolm X and Alex Haley. The Autobiography of Malcolm X. New York: Ballantine Books, 1990.

Mannoni, Dominique O. Prospero and Caliban: The Psychology of Colonization. New York: Praeger, 1964. 
Marx, Karl. Capital III. New York: International Publishers, 1977.

Ménil, René. Tracées: Identité, négritude, esthétique aux Antilles. Paris: Robert Lafont, 1981.

Mueller-Vollmer, Kurt. "Introduction: Language, Mind, and Artifact: An Outline of Hermeneutic Theory Since the Enlightenment." The Hermeneutics Reader. New York: Continuum, 1990.

Nancy, Jean-Luc. The Inoperative Community. Minneapolis: University of Minnesota Press, 1991.

O’Meara, John. "Introduction." City of God. By St. Augustine. New York: Penguin Books, 1984.

Ong, Walter J. Interfaces of the Word: Studies in the Evolution of Consciousness and Culture. Ithaca and London: Cornell University Press, 1977.

London: Yale University Press, 1967.

Poster, Mark. “A Second Media Age?" Arena Journal No. 3 (1994): 49-91.

$\rightarrow$ Ruccio, David F. "Failure of Socialism, Future of Socialists?" Rethinking Marxism 5.2 (Summer 1992): 7-22.

Said, Edward. “Orientalism Reconsidered." Cultural Critique (Fall 1985):89-107.

Spivak, Gayatri Chakravorty. The Post-colonial Critic: Interviews, Strategies, Dialogues. New York: Routledge, 1991.

Steiner, Georg. After Babel. New York and London: Oxford University Press, 1975.

Stephanson, Anders. "Regarding Postmodernism: A Conversation with Fredric Jameson." Postmodernism / Jameson / Critique. Ed. Douglas Kellner. Washington, DC: Maisonneuve Press,1989. 4374.

wa Thiong'o, Ngugi. Barrel of a Pen. Trenton, NJ: Africa World Press, 1982.

Weber, Max. The Protestant Ethic and the Spirit of Capitalism. New York: Scribners, 1958.

Wilkinson, Jan. Talking With African Writers. Portsmouth, NH: Heinemann, 1992.

Wyschogrod, Edith. Saints and Postmodernism: Revisioning Moral Philosophy. Chicago: University of Chicago Press, 1990. 